Association for Information Systems

AIS Electronic Library (AISeL)

Wirtschaftsinformatik 2021 Proceedings

Track 13: Social Media and Digital Work

\title{
Design Principles for Digital Upskilling in Organizations
}

Ann-Kristin Cordes

University of Münster, ERCIS, Münster, Germany

Julia Weber

University of Münster, ERCIS, Münster, Germany

Follow this and additional works at: https://aisel.aisnet.org/wi2021

Cordes, Ann-Kristin and Weber, Julia, "Design Principles for Digital Upskilling in Organizations" (2021). Wirtschaftsinformatik 2021 Proceedings. 5.

https://aisel.aisnet.org/wi2021/MSocialMedia13/Track13/5

This material is brought to you by the Wirtschaftsinformatik at AIS Electronic Library (AISeL). It has been accepted for inclusion in Wirtschaftsinformatik 2021 Proceedings by an authorized administrator of AIS Electronic Library (AISeL). For more information, please contact elibrary@aisnet.org. 


\title{
Design Principles for Digital Upskilling in Organizations
}

\author{
Ann-Kristin Cordes, Julia Weber \\ University of Münster, ERCIS, Münster, Germany, \\ cordes@ercis.uni-muenster.de, j_webe35@wwu.de
}

\begin{abstract}
The workforce of an organization plays a critical role for the success (or failure) of digital innovation; they need to have specific skills, which are required for creating the needed digital change. Therefore, organizations need to continuously upskill their workforce. Different ways to prepare and upskill the workforce for the digital future exist. However, a structured approach to guide organizations on how to retrain and upskill their workforce is lacking. In the light of this context, the research goal is to provide an action-oriented guideline in form of design principles supporting organizations to handle digital upskilling. To achieve this goal a hermeneutic literature review and semi-structured expert interviews as well as a focus group discussion have been performed to deduce design principles. Based on an applicability check proposed by Rosemann and Vessey [1], the usefulness and applicability of the resulting 15 design principles in organizations are validated.
\end{abstract}

Keywords: Digital Upskilling, Applicability Check, Design Principles, Digital Intelligence.

\section{Call for Digital Upskilling in Organizations}

Digitalization accelerates the spread and use of digital technologies like cloud services, big data, internet of things, artificial intelligence, and smart workspaces. Widespread adoption has a significant impact on how organizations stay competitive in today's globalized economy. It requires organizations to adapt their established business models and operations to keep pace with the ever-changing environment.

One crucial aspect of such a change is that digital systems and human systems coevolve and continuously transform each other. Companies like Facebook, Uber, Airbnb, and Alibaba were built to operate in a digital economy from the very beginning and can, therefore, be considered as pioneers in utilizing digital technologies to generate the highest possible business value [2]. On the other hand, companies that are not structured around a digital economy at their core need to go through a process of digital transformation in order to stay competitive, including their cyber and human systems [2]. For instance, companies like Henkel, L’Oréal, Voith, PriceWaterhouse Coopers $(\mathrm{PwC})$, and Amazon run upskilling programs to equip their workforce with the new skills and mindset to tackle organizational digital transformation, making sure that both their technology as well as their human resources are endowed with what they need to thrive [3-5]. This pattern shows that there is a global call for digital upskilling initiatives, although many organizations report that they lack the digital talent, i.e. 
"someone who is proficient in at least one of the 24 hard digital skills and in at least four of the eight soft digital skills" [6, p. 1], to run these initiatives successfully [6].

To successfully realize digital upskilling, organizations need to continuously upskill their workforce [7]. Putting the focus onto the workforce reveals widely discussed challenges like the increasing talent gap especially for digital skills [6]. There are different ways to prepare the workforce for the digital future: "retrain, redeploy, hire, contract, and release" [7, p. 50]. The latter four, redeploy, hire, contract, and release seem to be less appropriate because of the existing talent gap [3, 6, 7], budget restrictions [8], and the effort to integrate them in the organizational routines. That is why retraining is becoming more and more a reasonable approach for digital upskilling. However, a structured approach to guide organizations on how to retrain their workforce is lacking.

In the light of this context, the research goal is to provide an action-oriented guideline in form of design principles supporting organizations to handle digital upskilling of their workforce. No specific target workers are addressed in this article since the target workers depends on the focus of the intended digital upskilling initiative of the respective organization. It could be the whole workforce or only a specific department. The development of the design principles is based on the conceptual framework for developing organizational digital intelligence proposed by Cordes and Rosemann [9] as that framework is formulated on a high level of abstraction and a guideline for organizations on how to apply that framework is missing. Therefore, the main theoretical contribution is the instantiation of Cordes and Rosemann's [9] organizational digital intelligence framework by giving recommendations in form of design principles for applying the framework. By extending the framework, it demonstrates the applicability of it in the organizational context. Hence, it contributes to the context-extension [10]. The managerial contribution of this article is to provide a tangible artifact that guides organizations dealing with digital upskilling, aimed at facilitating digital upskilling. To achieve this goal a hermeneutic literature review and semi-structured expert interviews have been performed in order to deduce design principles. Based on an applicability check in form of a conducted focus group discussion proposed by Rosemann and Vessey [1], the usefulness and applicability of the design principles in organizations are validated.

In the remainder of this paper, the research background is introduced followed by the research method. Next, the design principles are presented and discussed. The paper concludes with potential limitations, and highlights future research opportunities.

\section{Theoretical Background}

\subsection{Organizational Digital Upskilling}

Digital upskilling refers to equipping the existing workforce with the right digital skills that enable them to participate in organizational digital transformation by providing learning and development offers that add value to the whole organization. It is one way of creating the workforce of the future [11]. It is a means to give "people the opportunity to gain the knowledge, tools, and abilities they need to use and 
understand advanced and ever-changing technologies in the workplace and their daily lives" [11, p. 2]. The aim is to teach them how to acquire the mindset and the behavior to confidently succeed in a digitally-enabled surrounding [11].

Digital upskilling can be done in three ways, that can also be applied in conjunction: (1) raising the workforce's capacity of skills, by teaching them new or different skills, (2) increasing the level of the workforce's existing skills, and (3) hiring entry-level employees to develop their skill set according to the organization's needs [7].

Organizations are already offering learning and development measures, including upskilling programs to equip their employees with the necessary skills. However, a survey about the investigation of a digital talent gap in companies of 753 surveyed employees working in the USA, Western Europe, or India reports not being satisfied with the upskilling programs offered by their organizations [6]. Moreover, $48 \%$ of the interviewed employees feel that they are not given enough time to attend upskilling opportunities. This leads to the observation that senior management and human resources departments need to ensure that the initiatives provided to the organization are perceived as both more attractive and more effective by the workforce, and that front-line managers actively encourage their employees to participate. In addition, employees should be given sufficient time to upskill [6].

Continuously informing the workforce about new ideas and plans for the organizational future helps to keep employees motivated to strive for the organization's goals. Staying connected and investing into the development of current employees promises more commitment and acceptance from their side and facilitates the management of the changing circumstances to be beneficial for the organization [8].

In conclusion, digital upskilling is crucial for organizations dealing with digital transformation [3]. Due to the widening talent gap [6] and budget limitations [8], digital upskilling is a reasonable alternative [7] for organizations to remain competitive in an increasingly digitally enabled business environment [2].

\subsection{Organizational Digital Intelligence Framework}

Cordes and Rosemann [9] introduce a conceptual framework entitled 'organizational digital intelligence framework', which addresses the organizational digital transformation from a dynamic-capabilities-perspective with a focus on the human resources of an organization. They define organizational digital intelligence "as [...] the capability of an organization to assess, understand, evaluate, implement and appropriately use digital technologies” [9, p. 4].

The framework has two layers, as displayed in Figure 1: the phase layer and the activity layer. The first layer consists of three phases that structure the process of developing digital intelligence in organizations. The phases are (1) digital ambition, (2) digital skills, and (3) digital literacy. The second layer contains more specific organizational activities, each related to one of the three phases [9].

The first phase of the digital intelligence framework, (1) digital ambition, aims at fostering a drive for continuous exploration of an organization's environment for technology-related opportunities to improve their business and build competitive advantage [9]. The activity, (1.1) scanning, refers to the effort of becoming aware of 
ideas for technology-driven change by searching external sources of information [9, 12]. The second activity, (1.2) shaping, relates to building on the results from the (1.1) scanning activity to develop and communicate a clear digital strategy along with the specification of required skill needs [9].

The second phase, (2) digital skills, intends to specify how an organization can develop the previously identified skills that are required to pursue the digital strategy and to provide an environment that enables the organization's workforce to acquire these skills successfully. The activity, (2.1) selecting, invokes the compiling of the desired skill portfolio. This means that an organization needs to identify the skills its workforce requires and to put it together in a selection of skills, that is a skill portfolio. These skills could already be available internally or could be taught through training offerings. The (2.2) structuring activity includes creating a learning infrastructure that enables the workforce to acquire the previously defined desired skillset. A wellthought-through learning environment and approach will help the workforce to create the motivation and the ability to acquire the required skills [9] .

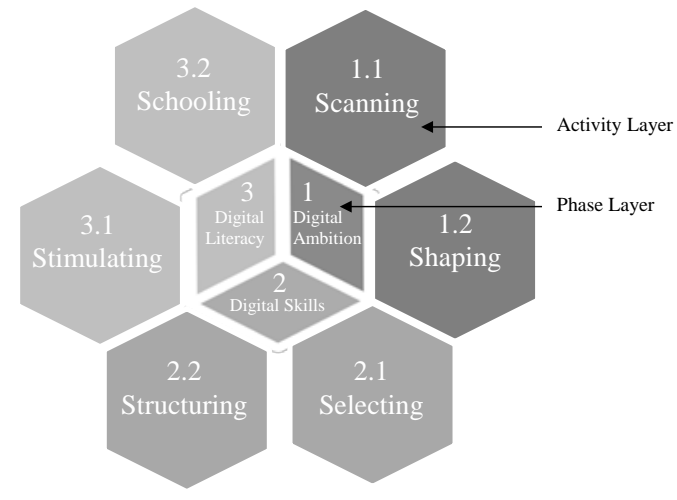

Figure 1. Organizational Digital Intelligence Framework: Phases and Activities [9]

The final phase of the organizational digital intelligence framework called (3) digital literacy, reflects a state of continuous alignment between the digital strategy and existing organizational operations. The phase includes the motivation and preparation of the workforce to pursue the organization's digital strategy and execute the needed change. (3.1) Stimulating includes inspiring and encouraging the employees to integrate the organization's digital strategy into their daily operations, making them develop their own ambition to strive for a digitally enhanced future, aligned with their organization's digital ambition. (3.2) Schooling is the second activity and comprises the actual teaching and acquisition of knowledge, and the learning process of the organization. During this activity, the workforce acquires the identified skills [9].

\section{Research Approach}

The article's goal is to define a guideline that helps organizations with designing digital upskilling initiatives. This guideline is presented in form of design principles (DP). 
Design principles are a method used in design science research "to specify design knowledge in an accessible form" [13, p. 1622] and popular due to their compactness and instructing action-oriented character [14] and therefore suitable for the research goal, because the developed guideline should comprise key aspects of a complex project described as compact as possible and prompting for specific actions. Gregor and Hevner [15] consider design principles as an artifact, originated from nascent design theory, that is more abstract allowing a condensed description of what to do.

In order to develop a preliminary set of design principles, different research methods are combined. First, a hermeneutic literature review proposed by Boell and CecezKecmanovic [16] and semi-structured expert interviews have been conducted. Moreover, the initial version of the design principles has been validated by conducting an applicability check in form of a focus group discussion [1].

In the context of this article, proceeding through the first circle of a hermeneutic literature review following Boell and Cecez-Kecmanovic [16] allowed an initial understanding of what is meant by digital upskilling in organizations, who is currently dealing with the topic in practice, and which organizations have already triggered such initiatives. The second circle was executed to identify major theoretical concepts that address digital upskilling in a narrow or broad sense and decide on methods for data collection, enabling the inclusion of practice-oriented information.

Qualitative data is gathered using semi-structured interviews, which allow a more detailed investigation around a set of fixed research topics. The interviews are used to investigate what recommendations can be given for organization when planning digital upskilling initiatives. To ensure a systematic and consistent procedure, an interview guide has been developed and used. It includes an introduction to the purpose of the interview and research, a set of central topics ((1) requirement definition, (2) initiative execution, (3) communication and change management, and (4) quality of initiative results) including predefined questions, anticipated probes and prompts, as well as closing comments. The interview questions were phrased based on previous knowledge, such as the central research goal, the findings of the literature review and the organizational digital intelligence framework [9, 17]. As interview partners, experts from the industry were chosen to improve the research relevance for practice. Each interviewee has a different organizational function and thereby introduces insights from different perspectives [17]. Each interview lasts 45-60 minutes to cover the topics defined in the interview guide in a satisfying depth [18]. The interviews are recorded and transcribed for a re-assessment at a later point in time. The content has been analyzed and embedded into the argumentation of each design principle [19]. Table 1 presents an overview of the three experts involved.

All experts interviewed are involved with the digital upskilling initiative at a German DAX30 company that operates globally in the business-to-business market as well as the business-to-consumer market. The organization is structured as a matrix organization with business units that each focus on one core business field of the organization and supporting corporate functions such as human resources, digital, finance, and IT. Interviewee 1 has been working for the selected organization for eleven years, with eight years of experience as head of the area learning and development. Interviewee 2 has been working at the same organization for 21 years, heading the 
collaboration topic for six years. The collaboration topic is part of the digital workplace team that is responsible for providing the tools and processes for the workforce to work digitally and initiate upskilling initiatives to enable the people to work within the provided workplace. Interviewee 3 works for the same organization as a business consultant on the topic of change management related to the introduction and use of ITrelated solutions. This person can draw from experiences with upskilling programs at other organizations, mainly German DAX companies. These experts were selected due to the diversity of areas and functions within the organization that they represent. It allows a thorough investigation from different and potentially opposing perspectives.

Table 1. Overview of the Interviewees

\begin{tabular}{|c|c|c|}
\hline Role of Interviewee & Data Collection Method & Reference \\
\hline Interviewee 1: & Semi-structured interview & Interview \#1 \\
\hline $\begin{array}{l}\text { Head of Learning and Development } \\
\text { (Human Resources Department; HR) }\end{array}$ & Focus group & Focus Group \\
\hline Interviewee 2: & Semi-structured interview & Interview \#2 \\
\hline $\begin{array}{l}\text { Head of Collaboration } \\
\text { (Information Technology Department; IT) }\end{array}$ & Focus group & Focus Group \\
\hline Interviewee 3: & Semi-structured interview & Interview \#3 \\
\hline $\begin{array}{l}\text { Change Management Expert } \\
\text { (Business Consultant with Psychology } \\
\text { Background) }\end{array}$ & Focus group & Focus Group \\
\hline
\end{tabular}

The results of the literature review together with three semi-structured expert interviews provided the basis for developing a preliminary set of design principles for digital upskilling. This work was done in a deductive approach [20] based on theories and ideas from literature and statements from the experts.

The preliminary set of design principles was then tested in one focus group discussion, according to the applicability check approach by Rosemann and Vessey [1]. As recommended by the authors [1], a focus group discussion can be conducted as an applicability check. During the focus group discussion, the role of the researcher is to act as a facilitator, encouraging the focus group members to exchange ideas with one another. This research approach enables the researcher to get insights into people's experiences, opinions, ways of thinking, and social interactions. It also allows the focus group members to highlight aspects important to them [21, 22].

One of the objectives of the focus group discussion is to examine any major discrepancies in the results. For each potential discrepancy, questions were prepared upfront and outlined in a dedicated guideline. Possible comments and questions are anticipated upfront and incorporated in the focus group guideline as well. Three focus group participants and two researchers took part in the discussion. The participants were selected because they have experience with a digital upskilling initiative recently launched in their organization; each of them brings in a different perspective, as they work in different departments and roles (see Table 1). The focus group discussion was limited to 60 minutes and took place at their organization's site. Prior to the focus group discussion, the set of 14 design principles for digital upskilling has been shared with 
the focus group for evaluation, so that the focus group discussion could focus on significant discrepancies only. A question guideline has been created and served as an orientation for the person conducting the check. It included a rough outline of what is to be covered during the discussion. However, it leaves enough room for the participants to freely exchange their opinions and add further comments if needed. For the analysis of the content, the core statements of the focus group discussion were noted and incorporated in the argumentation for each design principle.

\section{$4 \quad$ Design Principles for Digital Upskilling}

In the following it is elaborated how each of the design principles (DP) is built based on the supporting literature and how they are informed by statements from the expert interviews, as well as statements from the focus group discussion. Each design principle is formulated in a format that allows a focus on action and gives the desired outcome as proposed by Chandra et al. [14]. Table 2 gives an overview of the design principles.

Table 2: Design Principles for Digital Upskilling in Organizations

\begin{tabular}{|c|c|}
\hline Topic & Design Principle \\
\hline $\begin{array}{l}\text { Principle of Board } \\
\text { Sponsorship }\end{array}$ & $\begin{array}{l}\text { DP1: Define one board member, who is empowered by the } \\
\text { complete board, to drive the initiative and to articulate the } \\
\text { digital ambition. }\end{array}$ \\
\hline $\begin{array}{l}\text { Principle of } \\
\text { Dedicated Budget }\end{array}$ & $\begin{array}{l}\text { DP2: Provide budget, especially human resources dedicated to } \\
\text { digital upskilling exclusively, to ensure capacities and } \\
\text { commitment for executing the initiative. }\end{array}$ \\
\hline $\begin{array}{l}\text { Principle of Digital } \\
\text { Upskilling Team }\end{array}$ & $\begin{array}{l}\text { DP3: Form a digital upskilling team with diverse skills, topic } \\
\text { and change management experience, and access to an } \\
\text { organization-wide network to steer digital upskilling. }\end{array}$ \\
\hline $\begin{array}{l}\text { Principle of Vision } \\
\text { and Strategy }\end{array}$ & $\begin{array}{l}\text { DP4: Define a digital upskilling strategy that is closely linked } \\
\text { to the organization's digital strategy, to realize defined } \\
\text { objectives and to achieve the organizational digital vision. }\end{array}$ \\
\hline $\begin{array}{l}\text { Principle of } \\
\text { Stakeholders }\end{array}$ & $\begin{array}{l}\text { DP5: Identify and involve stakeholders in the preparation phase } \\
\text { who can potentially impede or promote organizational change } \\
\text { to reduce misunderstandings and obstacles. }\end{array}$ \\
\hline $\begin{array}{l}\text { Principle of } \\
\text { Planning and } \\
\text { Timing }\end{array}$ & $\begin{array}{l}\text { DP6: Define a detailed planning, with milestones and timings, } \\
\text { which allows for iterations of stages and activities, to prepare } \\
\text { and execute the initiative within time and budget. }\end{array}$ \\
\hline $\begin{array}{l}\text { Principle of } \\
\text { Workforce } \\
\text { Involvement in } \\
\text { Requirement }\end{array}$ & $\begin{array}{l}\text { DP7: Consult market trends, scientific research, consultancies, } \\
\text { upskilling experts, topic experts, and especially job-family } \\
\text { representatives to define digital skill requirements and levels } \\
\text { that reflect job-family-specific needs. }\end{array}$ \\
\hline
\end{tabular}




\begin{tabular}{|c|c|}
\hline Topic & Design Principle \\
\hline $\begin{array}{l}\text { Principle of Digital } \\
\text { Skill Level Review }\end{array}$ & $\begin{array}{l}\text { DP8: Analyze the digital skill set and level of each employee, } \\
\text { from different perspectives, to get insights on the organizational } \\
\text { status and the magnitude of upskilling. }\end{array}$ \\
\hline $\begin{array}{l}\text { Principle of Digital } \\
\text { Skill Fit }\end{array}$ & $\begin{array}{l}\text { DP9: Provide customized digital upskilling recommendations } \\
\text { to each employee, according to skill level and job family, to } \\
\text { offer personalized learning and development where required. }\end{array}$ \\
\hline $\begin{array}{l}\text { Principle of } \\
\text { Learning System }\end{array}$ & $\begin{array}{l}\text { DP10: Provide a learning system, with a comfortable } \\
\text { atmosphere, a convenient toolbox, and suitable training } \\
\text { content, to allow effective learning during work time. }\end{array}$ \\
\hline $\begin{array}{l}\text { Principle of Role } \\
\text { Models }\end{array}$ & $\begin{array}{l}\text { DP11: Engage workforce representatives, who are well- } \\
\text { recognized amongst their colleagues and can motivate them to } \\
\text { participate, to act as role models, to establish a link to the } \\
\text { workforce, and to reduce their concerns. }\end{array}$ \\
\hline $\begin{array}{l}\text { Principle of Benefit } \\
\text { Communication }\end{array}$ & $\begin{array}{l}\text { DP12: Publicize successful change and personal benefits, } \\
\text { things the workforce can relate to, to create interest and } \\
\text { ambition in the workforce to improve their digital skills. }\end{array}$ \\
\hline $\begin{array}{l}\text { Principle of } \\
\text { Communication } \\
\text { and Collaboration }\end{array}$ & $\begin{array}{l}\text { DP13: Utilize diverse communication channels, for a regular } \\
\text { exchange of information and knowledge with the workforce, to } \\
\text { manage expectations proactively, and to foster organization- } \\
\text { wide collaboration and organizational learning. }\end{array}$ \\
\hline $\begin{array}{l}\text { Principle of } \\
\text { Monitoring }\end{array}$ & $\begin{array}{l}\text { DP14: Define evaluation criteria, success factors and } \\
\text { mechanisms, that can reflect the skills set and level of the } \\
\text { workforce, to monitor the progress of the initiative and to } \\
\text { ensure sustainable digital upskilling. }\end{array}$ \\
\hline $\begin{array}{l}\text { Principle of } \\
\text { Interorganizational } \\
\text { Alliances }\end{array}$ & $\begin{array}{l}\text { DP15: Form or enter interorganizational alliances, with other } \\
\text { organizations who also work on digital upskilling, to exchange } \\
\text { best practices and lessons learned. }\end{array}$ \\
\hline
\end{tabular}

DP 1 - Principle of Board Sponsorship: Define one board member, who is empowered by the complete board, to drive the initiative and to articulate the digital ambition.

Within the organizational digital intelligence framework by Cordes and Rosemann [9] the responsibility for scanning the environment and articulating the organization's digital ambition is assigned to the top-level management of an organization [9, 23, 24]. Vahs [25] also sees the need for top-level management to be committed to the change, for it to be successful. An analysis of the expert interviews shows that it is prudent to have a board member sponsoring the initiative, for example, the head of human resources or the head of information technology (Interview \#2). It requires someone, like the chief executives, who invites the workforce to participate in the initiative. It is 
important that the workforce does not feel forced to participate but rather participates voluntarily (Interview \#2).

Further research shows that having the whole board support the organizational changes such as digital upskilling, can empower the coordination between the different areas in an organization [26]. This is also confirmed by expert interviews and the focus group discussion. The HR expert states that in addition to one board member who owns the initiative, the whole board should push the initiative and empower that person to drive the initiative (Interview \#1). The focus group agrees that all board members need to generally support the digital upskilling initiative to leverage its full potential.

DP 2 - Principle of Dedicated Budget: Provide budget, especially human resources dedicated to digital upskilling exclusively to ensure capacities and commitment for executing the initiative.

The principle of dedicated budget fits in the order after (1.2) shaping, because it assumes that a board member sponsors the initiative (see DP1).

Burnes [26] argues in his model for managing organizational change that it is prudent to dedicate specific resources to change projects. To fulfill that need, budget is to be dedicated specifically to change management. Additionally, the analysis of the expert interviews shows that there is a need for drawing attention to the importance of dedicating budget to digital upskilling. All interviewed experts (\#1 - \#3) report that they are often restricted in terms of time and resources that relate to budget. Besides, like Burnes [26], the experts point out that the workforce cannot cope with the change during their regular work time, while still delivering the same performance (Interview \#2, \#3). Thus, capacities and commitment for digital upskilling need to be ensured.

DP 3 - Principle of Digital Upskilling Team: Form a digital upskilling team with diverse skills, topic and change management experience, and access to an organization-wide network to steer digital upskilling.

According to the experts, it is "definitely important" (Focus Group) to have a team in place that manages digital upskilling. Burnes [26] also describes the need for creating a team that manages the change. In addition, as elaborated before, people cannot permanently deal with change on top of their normal job (Interview \#2, \#3), which is why resources should be allocated to managing digital upskilling. The team responsible for managing the digital upskilling in the organization should be diverse in terms of competences, background, and organizational function (Focus Group). The team should be populated with representatives of the different employee groups who are affected by the initiative, as well as topic experts from the different organizational areas (Interview \#1, \#2), a change expert, and a sponsor from the management board [26].

DP 4 - Principle of Vision and Strategy: Define a digital upskilling strategy that is closely linked to the organization's digital strategy, to realize defined objectives and to achieve the organizational digital vision.

Digital upskilling is a form of change, because it requires a transformation of the workforce [11]. Thus, it requires a strategy for its execution. Therefore, a clear strategy, concrete actions and a plan to execute them have to be defined to execute a digital upskilling initiative [9]. Each action can then be assigned to human resources who will be responsible for completing the action [26]. Vahs [25] remarks that it is crucial to communicate a clear vision for successful change. It is essential to set clear objectives, 
i.e., clearly defining what the outcome of the initiative should be (Interview \#3). The focus group recommends that the digital upskilling team has to clearly define what should be accomplished by running the initiative (Interview \#2, Focus Group) as clear objectives will provide a guidance [26].

DP 5 - Principle of Stakeholders: Identify and involve stakeholders in the preparation phase who can potentially impede or promote organizational change to reduce misunderstandings and obstacles.

Burnes [26] postulates that it is important to identify key people and groups within the organization who can promote or impede changes [9]. Johnson et al. [27] refer to those people as stakeholders, providing the following definition: "Stakeholders are those individuals or groups who depend on an organization to fulfill their own goals and on whom, in turn, the organization depends” (Focus Group). Further, it is important to identify the people in the organization who have an influence on the collective opinion of the people who surround them. It is crucial to involve these people and to make sure they understand the reasons and urgency for the planned change. If they favor the change, it is likely that the people on whom they have an influence also tend to favor the change. If they do not favor the change, the opposite can happen [26]. The expert interviews reveal that it is judicious to consider the following type of people as stakeholders for digital upskilling in order to reduce misunderstandings and obstacles: (1) the workforce as a whole, especially those who are affected by the digital upskilling, (2) the area representatives who are involved in the requirement definition, (3) the sponsor of the initiative, and (4) the board of directors (Interview \#1; Interview \#2).

DP 6 - Principle of Planning and Timing: Define a detailed planning, with milestones and timings, which allows for iterations of stages and activities, to prepare and execute the initiative within time and budget.

This design principle has the goal to raise the awareness of how important it is to have a planning that considers the defined objectives of the initiative and formulates a procedure that shows how to achieve the objectives [26, 28, 29]. The interviewed change expert also highlights the importance of defining a clear planning with milestones, timings, and allocation of the responsibility for meeting them to the digital upskilling team (Focus Group). It was said that it is difficult to define realistic timings for most of the activities, especially iterative ones (where the number of required iterations may not be known). But the publication of the trainings, timings, or rather deadlines can be a means to convey the urgency of the participation in the initiative to the workforce (Focus Group). Vahs [25] also states that a lack of understanding the urgency of the change is factor for failure of organizational transformation.

DP 7 - Principle of Workforce Involvement in Requirement Definition: Consult market trends, scientific research, consultancies, upskilling experts, topic experts, and especially job-family representatives to define digital skill requirements and levels that reflect job-family-specific needs.

Aguninis [30] argues from a performance management perspective that people who are involved in the creation of something are more willing to "support what they help create” [30, p. 172]. Wilson [31] states that organizational change could fail if the people affected by the change are not involved. Giving responsibility to the people will most likely make them more likely to support the change [26]. According to the 
interviewed experts, it seems most effective to visit team meetings, to talk to people personally, to accompany them during their daily work and - most importantly - to "listen to the organization" (Interview \#2), granting the word-of-mouth high importance (Interview \#1). But also the topic experts from areas like finance or marketing should provide their input, to make sure the skill requirements reflect jobfamilies' specifics (Interview \#2, \#3). A job-family is a cluster of jobs with the same or very similar qualification profiles like salespersons. The digital intelligence framework by Cordes and Rosemann [9] addresses the need for defining a skills portfolio to deal with digital transformation in organizations in the form of establishing digital intelligence. The activity that comprises the skill portfolio definition is called (2.1) Selecting.

DP 8 - Principle of Digital Skill Level Review: Analyze the digital skill set and level of each employee, from different perspectives, to get insights on the organizational status and the magnitude of upskilling.

The knowledge about the current skill set and level of the workforce, enables the management to decide what other measures are necessary to digitally upskill the workforce. According to McKinsey Global Institute, there are five actions to equip the workforce with the digital skills that will be needed to handle digital transformation successfully: "retrain, redeploy, hire, contract, and release" [7, p. 50]. The key challenge for surveying the digital skill set and level of the employees is that it varies day-to-day (Focus Group). Ideally, an information technology system would analyze the skill sets and levels of the individual employees, providing customized development measures to each employee, but that is currently not yet possible (Focus Group).

DP 9 - Principle of Digital Skill Fit: Provide customized digital upskilling recommendations to each employee, according to skill level and job-family, to offer personalized learning and development where required.

The provision of customized upskilling measures makes it more likely that the affected people are more willing to make use of the offers and pursue the continuous improvement [26] of their digital skills. It is important to make sure the workforce effectively benefits from the digital upskilling initiative (Interview \#1 - \#3). It seems reasonable to train job-family-specific skills, such as digitalizing content in the marketing area, or utilizing sales-specific applications in the sales area (Interview \#2).

DP 10 - Principle of Learning System: Provide a learning system, with a comfortable atmosphere, a convenient toolbox, and suitable training content, to allow effective learning during work time.

External providers can provide training material for the basic functionalities of employed tools. When it comes to organization-specific content, area representatives may have to contribute (Interview \#1). The HR department is responsible for preparing organization-specific learning and development offers (Interview \#2). The training material for digital upskilling is often a combination of content provided by digital solution providers (e. g., Microsoft), organization-specific material provided by the HR department, and job-family-specific content provided by the job-family-representatives and topic experts (Interview \#2). In addition, the workplace should be designed to inspire the employees to acquire new ways of working [11]. Furthermore, Cordes and 
Rosemann [9] emphasize to design a motivating learning environment for successful digital upskilling in the activity (2.2) structuring.

DP 11 - Principle of Role Models: Engage workforce representatives, who are well-recognized amongst their colleagues and can motivate them to participate, to act as role models, to establish a link to the workforce, and to reduce their concerns.

The principle of role models is intended to express the importance of supporters in the organization who are enthusiastic about digitally upskilling themselves and who delightedly motivate their colleagues also to upskill themselves. The term role models, "a person looked to by others as an example to be imitated," [32] was chosen because it is a commonly known and understood term and because it summarizes all other potential terms mentioned by the interviewed experts that express the same idea, such as key users (Interview \#2), ambassadors (Interview \#3) or gurus (Interview \#1), freeing them from company-specifics or relying on area-specific knowledge. Key users, for instance, is a term that is often used amongst the employees of the information technology department (Interview \#2). Cordes and Rosemann [9] point out the need for motivating the workforce to take part in digital upskilling, expressed in form of the first activity of the (3) digital literacy phase in their framework: (3.1) stimulating. The design principle of role models refers to those people in the organization who embody a role model function, inspiring others, independent of their formal role [26] and are willing to push change on top of their normal duties.

DP 12 - Principle of Benefit Communication: Publicize successful change and personal benefits, things the workforce can relate to, to create interest and ambition in the workforce to improve their digital skills.

Cordes and Rosemann [9] draw the attention to the need for motivating the workforce to upskill themselves, conveyed in the (3.1) stimulating activity of the (3) digital literacy phase of their framework. (3.1) Stimulating aims to raise the workforce's ambition to become digitally upskilled [9]. In addition to engaging role models for motivating the workforce's participation, communicating the benefits that the initiative brings to the employee's daily work and their personal life is an option [26]. Even though it is important to make the workforce aware of the benefits they receive from digital upskilling, it is a challenge to do so on an individual basis (Focus Group). Moreover, it can be supportive if the trained workforce sees that the offered solution works properly and can effectively improve their daily work (Interview \#3).

DP 13 - Principle of Communication and Collaboration: Utilize diverse communication channels, for a regular exchange of information and knowledge with the workforce, to manage expectations proactively, and to foster organization-wide collaboration and organizational learning.

Communication is key for an organization going through a process of change [26]; communication should be bi-directional between the people affected by the change and the people managing the change [25]. It is important to provide and use channels for regular two-way communication encouraging employees to talk about and understand their ideas and concerns. The interviewed experts recommend making use of diverse communication channels, "to meet the people where they are" (Focus Group). This allows the change management team to better understand what drives the workforce and what fosters their willingness to learn. Keeping up the communication to the people 
affected by the digital upskilling initiative is advisable [31]. The focus should be on presenting features that are beneficial for them (Interview \#2), connecting use cases to the different job-families to which they apply (Interview \#3).

DP 14 - Principle of Monitoring: Define evaluation criteria, success factors and mechanisms, that can reflect the skills set and level of the workforce, to monitor the progress of the initiative and to ensure sustainable digital upskilling.

Change is an ongoing process that needs continuous management [26]. To assure that the defined digital upskilling objectives are achieved, it is required to monitor the progress of ongoing activities [26] and the skill level of the employees by collecting feedback [26]. Experience shows that training evaluation surveys are "happy sheets" asking questions like "did you like the training?" and "was the trainer nice?”. Instead, a personal conversation may reveal more constructive feedback that can show whether people have actually understood the training and can apply their newly acquired skills (Interview \#3). Therefore, for monitoring the progress of the organization, it is essential to maintain contact with the people by talking to the teams, joining their team meetings, and providing interactive question and answer sessions, because the progress of digital upskilling cannot be measured by only regarding hard facts, like number of emails sent (Interview \#3). Therefore, it is crucial to "listen to the organization" (Interview \#2). since (3.2) schooling focuses on the organizational learning process [9] that should be monitored regularly, to ensure the sustainability of digital upskilling.

DP 15 - Principle of Interorganizational Alliances: Form or enter interorganizational alliances, with other organizations who also work on digital upskilling, to exchange best practices and lessons learned.

The focus group discussion has crystalized the demand for interorganizational cooperation in regards to digital upskilling in organizations. In addition, one of the experts articulated strong interest in the results of further research regarding digital upskilling that is aimed at surveying other organizations about their approaches to digital upskilling, in addition to: "I sense that all the companies are at the same point. And all are struggling with the same things. So, if these people would exchange on the lessons learned, that would help. Because everyone is doing the same mistakes in this" (Focus Group). Furthermore, surveys published by consultancies prove that there are many organizations nowadays dealing with digital upskilling [33]. Therefore, it seems to be a strong demand for a knowledge exchange with other organizations, to learn from their mistakes and to generate best practices. However, even though the experts seem to be aware of other companies dealing with digital upskilling, their organization is not part of an interorganizational alliance on digital upskilling (Focus Group).

\section{Discussion}

\subsection{Final Set of Design Principles}

The previous section presented the final set of design principles. One challenge was to find the right amount of design principles and the appropriate level of detail each of the design principles expresses. The aim was to avoid overwhelming the audience with 
too many or too detailed design principles while ensuring to cover the most important aspects at a level of detail that is useful for people applying the guideline to practice. The set of principles was established through an iterative approach of adapting the content and formulation throughout the research.

The design principles that were developed are intended to be generic enough to serve different types of organizations while being detailed enough for practitioners to get an adequate overview of concrete actions required for a successful digital upskilling in their organization. However, smaller organizations who operate regionally or locally, or organizations that do not have a central human resources department and information technology department that have a corporate reach, may need a slightly modified set of design principles. For instance, organizations without a management board but a single director, would need to interpret the principle of board sponsorship as the principle of organizational head sponsorship. A reoccurring statement in literature and the conversations with experts also confirms that there is no one-size-fits-all-approach for digital upskilling in organizations. Therefore, the set of design principles developed in this article may need minor modifications for each specific use case.

The conducted research and the results of the focus group discussion emphasized that it is required to distill meaningful design principles, comprising all key aspects, in a single sentence. Still, the provision of further explanation seems recommendable, since the focus group discussion revealed that people might interpret individual terms differently, that simply cannot be avoided completely just in the phrasing of one sentence.

The design principles of role models and benefit communication could be combined because both are related to motivating the workforce to participate in the initiative. However, both aspects are important for themselves and were mentioned by the experts explicitly (Focus Group; Interview \#1 - \#3). Therefore, they are listed as separate design principles to give each of them sufficient attention, especially in the first reading of the presented set of design principles.

The measures of motivating the workforce to participate in digital upskilling, focus on non-monetary incentives, such as higher reputation as a result of successful upskilling, gamification of the upskilling results, and clearly visualizing the added convenience for their daily work. The reported expert experience suggest that nonmonetary incentives are more effective than monetary incentives. The decision on which kind of incentive to employ depends on the organizational setup, the culture, and the desired outcome of the planned initiative. Therefore, monetary incentives should also be considered as a reasonable means to get people engaged with digital upskilling.

\subsection{Modifications of Design Principles After the Focus Group Discussion}

As an outcome of the focus group discussion, minor changes in the wording of the following design principles for digital upskilling were made and one additional design principle was formulated.

The principle of benefit communication originally stated 'Publicize personal benefits and success to create intrinsic motivation [...]', but the first part was rephrased because the focus group agreed that it is difficult for the digital upskilling to generate 'intrinsic 
motivation' in the workforce for participating in the initiative. The change management expert argued that it is something very personal and hard to influence, and the other focus group members agreed (Focus Group). Therefore, 'intrinsic motivation' was rephrased to 'interest and ambition' that all discussants agreed on (Focus Group).

The design principle of workforce involvement in requirement definition does not further specify an additional boundary condition, because it does not seem to be adding value to the message of the design principle but rather prolongs it unnecessarily. Therefore, no explicit boundary condition was phrased because the principle was understood and perceived as important and applicable by the participants of the focus group discussion (Focus Group).

The principle of communication and collaboration was also rephrased. The focus group pointed out that the original wording excludes, for example, emails, from the scope of the design principles by referring to communication platforms. Since emails are a crucial part of the communication, the participants suggested the term communication channels instead of platforms. In addition, the focus group highlighted the importance of utilizing existing communication channels, to "meet the people where they are", that can be diverse and should be used regularly (Focus Group).

Even though the focus group confirmed that the developed set of design principles does not lack any key aspects and that it can serve as an adequate starting point for other organizations dealing with digital upskilling, the principle of interorganizational alliances was added to further enhance the final set of design principles. While the principle of stakeholders and the principle of workforce involvement in requirement definition, both addressing the cross-functional cooperation, were pointed out as vital design principle one additional design principle was deduced from the discussions. Especially the following statements led to the decision to enhance the set of design principles by adding a principle of interorganizational alliances: "I sense that all the companies are at the same point. And all are struggling with the same things. So, if these people would exchange on the lessons learned, that would help. Because everyone is doing the same mistakes in this” (Focus Group).

\section{Conclusion}

The aim of this article was to develop a set of design principles for digital upskilling that enhances the organizational digital intelligence framework [9] by providing guidance on how to apply the framework. The developed set of 15 design principles is supposed to be phrased generically enough to be applied in different kinds of organizations as well as sufficiently detailed to enable practitioners to get an adequate impression of what aspects to consider when designing digital upskilling initiatives in their organization. The guideline shall help employees who are in charge of designing and executing a digital upskilling initiative with an organization-wide reach.

As with every research, this paper is subject to limitations and leaves room for further research work. Future research could focus on developing a set of methods, along with decision criteria regarding the method selection, for each of the design principles. Each of the presented principles would benefit from a collection of methods 
developed to provide guidance on possible approaches to conform with the principle. Moreover, the perspectives of other organizational areas than those departments represented by the interviewed experts could be examined how they perceive digital upskilling. The clear demand for personalized upskilling recommendations suggests that further research could focus on developing a system or technology that can analyze the employees' skills set and levels and make recommendations based on that analysis.

Concluding, digital upskilling initiatives are a suitable approach for upskilling the workforce of organizations, enabling them to thrive in an increasingly digital future. The herein presented design principles provide an adequate guideline for designing and executing digital upskilling in organizations.

\section{References}

1. Rosemann, Vessey: Toward Improving the Relevance of Information Systems Research to Practice: The Role of Applicability Checks. MIS Quarterly 32, 1 (2008)

2. Gimpel, H., Röglinger, M.: Digital Transformation: Changes and Chances Insights based on an empirical study. Augsburg, Bayreuth (2015)

3. Moritz, B.E., Ryan, T., Davies, M., Ellis, K., Oldfield, R., Steffen, I., Kayser, H., Hyde, S., Mallon, H., Chao, R., et al.: Navigating the rising tide of uncertainty (2020)

4. Stubbings, C.: The case for change: New world. New skills., https://www.strategy-business.com/blog/The-case-for-change-New-world-newskills?gko=1482a

5. Wittenhagen, J.: Wir stehen am Beginn einer Lernreise. Digital Upskilling bei Henkel. Lebensmittel Zeitung (2019)

6. Buvat, J., Crummenerl, C., Slatter, M., Puttur, R.K., Pasquet, L., van As, J.: The Digital Talent Gap. Are Companies Doing Enough? (2017)

7. Bughin, J., Hazan, E., Lund, S., Dahlström, P., Wiesinger, A., Subramaniam, A.: Skill shift. Automation and the future of the workforce (2018)

8. Heath, B., Christidis, A.: Invest In People to Best Manage Through Disruption. Employee development may be a complex, long-term priority, but it's more effective than short-term responses to disruption. MIT Sloan Management Review (2020)

9. Cordes, A.-K., Rosemann, M.: Developing organizational digital intelligence: A conceptual framework. In: 28th European Conference on Information Systems 2020 (2020)

10. Berthon, P., L. Pitt, M. Ewing and L. Christopher: Potential research space in MIS . A framework for envisioning and Evaluating Research Replication, Extension, and Generation. Information Systems Research 13, 416-427 (2002)

11. Stubbings, C., Sethi, B., Brown, J.: Talent trends 2019. Upskilling for a digital world (2019)

12. Albright, K.S.: Environmental scanning: Radar for success. The Information Management Journal 38, 38-44 (2004) 
13. Gregor, S., Chandra Kruse, L., Seidel, S.: The Anatomy of a Design Principle. Journal of the Association for Information Systems 21, 1622-1652 (2020)

14. Chandra, L., Seidel, S., Gregor, S.: Prescriptive Knowledge in IS Research: Conceptualizing Design Principles in Terms of Materiality, Action, and Boundary Conditions. In: 2015 48th Hawaii International Conference on System Sciences, pp. 4039-4048. IEEE (2015)

15. Gregor, S., Hevner, A.R.: Positioning and Presenting Design Science Research for Maximum Impact. MIS Quarterly 37, 337-355 (2013)

16. Boell, S.K., Cecez-Kecmanovic, D.: A Hermeneutic Approach for Conducting Literature Reviews and Literature Searches. CAIS 34 (2014)

17. Wilson, C.: Semi-Structured Interviews. In: Interview Techniques for UX Practitioners, pp. 23-41. Elsevier (2014)

18. Robson, C., McCartan, K.: Real world research. A resource for users of social research methods in applied settings. Wiley, Chichester (2016)

19. Gläser, J., Laudel, G.: Experteninterviews und qualitative Inhaltsanalyse als Instrumente rekonstruierender Untersuchungen. VS Verlag, Wiesbaden (2010)

20. Saunders, M., Lewis, P., Thornhill, A.: Critically reviewing the literature. Chapter 3. In: Saunders, M., Lewis, P., Thornhill, A. (eds.) Research methods for business students, pp. 58-105. Pearson Education, Harlow (2009)

21. Kitzinger, J.: Qualitative research. Introducing focus groups. BMJ (Clinical research ed.) 311, 299-302 (1995)

22. Nyumba, T.O., Wilson, K., Derrick, C.J., Mukherjee, N.: The use of focus group discussion methodology: Insights from two decades of application in conservation. Methods Ecol Evol 9, 20-32 (2018)

23. Teece, D.J., Pisano, G., Shuen, A.: Dynamic Capabilities and Strategic Management 18, 509-533 (1997)

24. Teece, D.J.: Dynamic capabilities as (workable) management systems theory. Journal of Management \& Organization 24, 359-368 (2018)

25. Vahs, D.: Organisation. Ein Lehr- und Managementbuch. Schäffer-Poeschel, Stuttgart (2012)

26. Burnes, B.: Managing Change. Pearson Educación, Harlow (2004)

27. Johnson, G., Scholes, K., Whittington, R.: Exploring corporate strategy. Prentice Hall, Harlow (2009)

28. Kotter, J.P.: Leading Change: Why Transformation Efforts Fail. Harvard Business Review, 57-67 (1995)

29. PMI: A guide to the project management body of knowledge. (PMBOK guide). PMI, Newtown Square, Pa. (2008)

30. Aguinis, H.: Performance management. Pearson, Boston (2013)

31. Wilson, J.P.: Human resource development. Learning \& training for individuals \& organizations. Kogan Page, London, Sterling, VA (2005)

32. LEXICO: Role Model | Meaning of Role Model by Lexico, https://www.lexico.com/definition/role_model

33. Sethi, B. and Stubbings, C.: Upskill my workforce for the digital world, https:/www.pwc.com/gx/en/services/people-organisation/upskill-my-workforcefor-the-digital-world.html 